\title{
The Developing Path of Double Qualified Teachers of Applied Colleges and Universities \\ YONG Chunguang
}

\author{
Baicheng Normal University, Baicheng, 137000, China \\ email: xiaoyong0619@163.com
}

Keywords: Applied Colleges and Universities, Double Qualified Teachers, The Developing Path

\begin{abstract}
With the continuous development of society, the demand for applied talents in various industries is also rising. Colleges and universities in our country must transform into application-oriented colleges and universities according to the market demand as soon as possible. It is very necessary to study the cultivation path of double qualified teachers in applied colleges and universities. Based on the analysis of the definition and connotation of qualified teachers. This paper will deeply analyze the problems existing in the training process of teachers with dual abilities and teachers in colleges and universities at present, and study the specific ways of training on the basis of these contents.
\end{abstract}

\section{Introduction}

Under the traditional education mode, most college teachers will focus on understanding and mastering the content of teaching materials, and such teaching mode will not only cause the students to reduce their practical ability. It will also cause students to find employment in the process of difficult to meet the requirements of employers. Under such a background, colleges and universities must be aimed at the traditional training model reform. Building the double qualified teachers team is one of the main ways to solve this problem. Double qualified. teachers can train students' professional knowledge and practical skills at the same time. In order to better ensure that double qualified teachers can play its role in colleges and universities, universities can also achieve the goal of cultivating application-oriented talents. This article will carry on the research to this kind of teacher's training path.

\section{Brief Introduction of Related Concepts and Connotations}

Applied Colleges and Universities. The concept of application-oriented university comes from the increasing demand for high-quality applied talents in various fields of society. According to the analysis above, under the traditional teaching mode. The practical skills mastered by students are inevitably difficult to meet the requirements of employers. At the same time, the upgrading of teaching materials in colleges and universities is very slow compared with the development of each industry itself. If college teachers can only rely on the content of textbooks for teaching, then when students enter the job. It is inevitable that it will be difficult to adapt to the working environment or even to complete the normal work content. Under this background, in 2014, our government clearly put forward the goal of vigorously developing applied undergraduate colleges[1].

It needs to be clear that the concept of application-oriented undergraduate is corresponding to the research-oriented undergraduate, compared with the application-oriented undergraduate, it pays more attention to the cultivation of students' practical skills. And in the process of cultivating talents, the market demand is regarded as the main direction. Based on this theory, the applied colleges and universities should adjust the traditional training objectives and curriculum structure. The choice of teachers and the construction of teachers' team are the key to the achievement of this goal. Double qualified teachers. On the basis of a certain theoretical knowledge, there is also a wealth of practical knowledge. In the actual teaching process, students' practical ability can naturally be effectively improved. From this point of view. The key to the development of applied universities is to train double qualified teachers and set up specialized teachers in colleges and universities. 
Double Qualified Teachers. Double qualified teachers and traditional college teachers are different in essence[2]. It is not difficult to find on the cultivation of the original mode of analysis, most of the teachers in the teaching process dependent on textbooks are very strong, and because the content of the textbook and relative lag of development of the industry, not only the practical ability of students to be effectively enhance students can master the skills is likely to have been eliminated by the market, the students in the process of job employment will inevitably lead to various problems. With this background, the development demand in the application of high school, according to the double qualified teachers training is very necessary.

Double qualified teachers mainly refers to the teachers who have both the qualification certificate and the relevant professional skill certificate, and on this basis. These teachers should have some practical experience at the same time, so as to ensure that teachers can adjust the teaching plan according to the development of industry and market demand in the teaching process, compared with the research-oriented colleges and universities. The requirements of applied colleges and universities for teachers are relatively high, except for the requirements of teaching ideas and teaching methods. Double qualified teachers should also have a high degree of professionalism, based on the training of students' professional knowledge and skills. These teachers should also combine their own experience to guide students in the process of employment and subsequent work to effectively bring into play what they have learned in school in order to ensure that students can better meet the needs of employers[3].

\section{The Problems Existing in Double Qualified Teachers Cultivation in Applied Colleges and Universities at the Present Stage}

The Choice of Teachers. Most universities in our country belong to research-oriented colleges and universities. They pay more attention to the graduation schools and academic qualifications of teachers in the process of selecting teachers, ignoring the practical skills and experience mastered by teachers. College teachers mainly come from various normal colleges and universities, and although this part of teachers have mastered certain teaching methods and basic knowledge, but most of these teachers do not have relevant industry experience, lack of teaching experience. Naturally, it is difficult to meet the requirement of cultivating students' practical skills in applied colleges and universities. For some teachers with strong professional skills, this part of teachers may be rejected by colleges and universities because their academic qualifications are not up to the requirements. If application-oriented colleges and universities can not be aimed at such a situation of reform. Therefore, the cultivation of double qualified teachers in colleges and universities will be affected to some extent[4].

Lack of Practical Ability of Teachers. Combined with the above content, most of the teachers in colleges and universities are directly from the school to the post of teachers, this is also true for the application-oriented universities discussed in this paper. In the actual teaching process. Most of the teachers can only start teaching according to the content of the teaching material, but under this teaching mode. Students' knowledge can only be limited to the scope of textbooks. For some teachers who have some practical experience, because of short practice time or teachers' own work attitude. Most of the practical skills mastered by these teachers flow on the surface, and it is difficult to meet the requirements of the society and industry for college graduates. The lack of practical skills and practical experience of college teachers is one of the main problems to be solved in the process of cultivating double qualified teachers in applied colleges and universities.

Lack of Incentive Mechanism for Teaching in Colleges and Universities. The establishment of teaching incentive mechanism will greatly affect the enthusiasm of teachers in the process of teaching[5]. The same is true for the double qualified teachers discussed in this paper, and in order to ensure that the training of this kind of teachers can play a better role. Application-oriented colleges and universities must develop a new teaching incentive mechanism for double qualified teachers, which has been mentioned above. The concept of "double qualified teachers" not only puts forward higher requirements for teachers in terms of professional skills, but also requires teachers to improve their professional qualities to a certain extent, and in view of the present situation. Most 
colleges and universities do not set up a new reward and punishment mechanism for double qualified teachers. Such a situation will naturally lead to teachers' enthusiasm for teaching by a certain extent. At the same time. Double qualified teachers must be able to continuously update its teaching concepts and skills in the light of the development of markets and industries. Without the support of perfect teaching reward mechanism, the enthusiasm and initiative of teachers in this process will be greatly affected, which will lead to the difficulty to achieve the goal of cultivating students in applied colleges and universities.

\section{The Developing Path of Double Qualified Teachers of Applied Colleges and Universities}

Deepening the Understanding of the Importance of Cultivating Double Qualified Teachers. All administrative and teaching assistants should realize the importance of training double qualified teachers. As far as the employment situation of college students in our country is concerned. The employment pressure of college students is very great, and whether the students' knowledge and skills can meet the requirements of enterprises has become one of the main factors that affect the employment situation of college students. Universities and university teachers should adapt to the needs of the market and related industries to adjust the original training objectives and teaching model. Obviously, the traditional research-oriented university teachers can not meet such needs. Colleges and universities must combine the idea of "two teachers and two abilities" to train teachers[6].

In order to ensure the smooth development of this work, colleges and universities can through the following aspects to enhance the understanding of the importance of all personnel in colleges and universities.First, promotion of double qualified teachers by University leaders. Awareness of the importance of the work. The awareness of the importance of the work carried out by the leadership is the key to its effectiveness. Colleges and universities can carry out training for this part of personnel to assist university leaders to understand the definition and connotation of double qualified teachers. On the basis of this, this paper expounds the importance of cultivating this kind of teachers in applied colleges and universities, only in this way. The development and implementation of double qualified teachers training program can better achieve the expected goal. Second, through propaganda activities to create a good atmosphere of public opinion. Under the influence of the traditional training model, some teachers and related staff in colleges and universities are difficult to accept the teaching model and the transformation of the work model quickly. In order to solve this problem, the enthusiasm displayed in double qualified teachers training process is not high, which results in the effect of training being affected. Colleges and universities should deepen teachers' knowledge of double qualified teachers by propagating the concept of "two teachers and two abilities" and carrying out related teaching and research activities within the campus. To identify with. In the campus to form a good atmosphere, to achieve the result of everyone competing for double qualified teachers. Then ensure that the whole teaching staff of colleges and universities can meet the specific requirements of double qualified teachers.

Draw up a Plan from two Aspects of Talent Introduction and Talent Training. The cultivation of double qualified teachers is a long-term task, therefore. Applied colleges and universities must be able to work out a sound plan for the development of this work. In the process of making and implementing the plan. Colleges and universities must pay equal attention to the external introduction and internal talent training as the basic principle. For the development of talent introduction, applied colleges and universities should avoid only through academic qualifications, graduate schools and other factors to choose teachers. It should be combined with the specific requirements of double qualified teachers. From the practical skills and professional knowledge of the two aspects of the comprehensive selection of the introduction of talent. In the case of conditions permitting, colleges and universities can be combined with the needs of the development of the industry. Teachers with certain working experience will be introduced into the actual teaching process, and thus better ensure the internal cultivation of students' practical ability. In this process, colleges and universities should first take the cultivation of double qualified teachers as the ultimate goal. And combined with this content to set a stage of short-term goals, 
gradually improve the teaching level of teachers themselves and the overall level of teachers in colleges and universities. Secondly, colleges and universities should be "advanced driving, point-to-face combination." As a basic principle in the process of this work, the whole development of the teachers through the experience of rich, practical skills of teachers to drive other teachers. Finally, the formulation of this plan should be operable and feasible. In the process of making the plan. Relevant staff in colleges and universities should not only focus on the current, but also analyze the long-term development of various industries. The short-term and long-term goals of double qualified teachers cultivation in colleges and universities are defined in combination with these two contents[7].

Perfecting the System of Double Qualified Teachers. As mentioned above, the requirements for double qualified teachers and college teachers are completely different. So colleges and universities should set up new management methods and system for this part of teachers. In order to ensure the enthusiasm and initiative of teachers in the process of actual work, aiming at double qualified teachers. The improvement of relevant system mainly includes salary and treatment. Evaluation and assessment, teaching and research and other aspects, this paper mainly describes the following points. First, evaluation and examination. The evaluation and evaluation of double qualified teachers should be determined according to the actual results. Colleges and universities should still be combined with the teaching process of teachers involved in the practice of the content of the overall content of the proportion of teaching and students to grasp the situation of practical skills to measure. For such a requirement. In addition to direct examination of students' practical skills. Colleges and universities can also through the form of questionnaires to directly understand from the group of students whether teachers in the process of practical skills teaching can meet the requirements of applied universities. Second, incentive system. The determination of incentive system is the key to ensure the effect of double qualified teachers training in applied colleges and universities. Colleges and universities should try to distinguish double qualified teachers from ordinary teachers. Through the targeted incentive system to stimulate teachers to constantly improve their own skills and professional level. And through the establishment of this system to stabilize the double qualified teachers team in colleges and universities as soon as possible.

\section{Establishing a Training Platform for School-Enterprise Cooperative Teachers}

It is not difficult to find that the lack of practical experience and practical skills is the main reason why college teachers can not reach double qualified teachers. For this point, applied colleges and universities should train the relevant teachers through the mode of cooperation between schools and enterprises. For university teachers, colleges and universities can encourage these teachers to go from school to real jobs. Understand the specific needs of professional personnel, and through participation in the actual work process to better grasp the relevant practical skills. And then ensure that this part of the teachers in the teaching process is better for the practical skills of students to teach. On the other hand. Colleges and universities can directly invite senior engineers or other senior staff to participate in the teaching process, compared with ordinary teachers. This part of the personnel in the knowledge and skills more close to the actual needs of the enterprise, at the same time, for the cultivation of practical skills of students. Students can also more timely access to the latest development direction and needs of related industries through the enterprise internal personnel.

\section{Conclusion}

To sum up, this paper firstly analyzes the existing problems in the process of double qualified teachers cultivation in colleges and universities in China. Combined with these contents, we can improve the understanding of the importance of cultivating double qualified teachers among the relevant personnel in colleges and universities, and make a perfect training plan. Improve the management system for double qualified teachers. This paper analyzes the training path of double 
qualified teachers in applied colleges and universities in four parts, such as the establishment of cooperative training platform for colleges and enterprises, and so on. Set up a perfect team as soon as possible. The double qualified teachers team with a certain teaching level is the key to ensure that the application-oriented colleges and universities can better achieve their training goals. Colleges and universities must combine their own development as well as the requirements of various industries for college graduates to train double qualified teachers.

\section{Acknowledgement}

In this paper, the research was sponsored by the Educational Science Project of Jilin province during “13th Five-Year Plan” in 2017 (No. GH170590) .

\section{References}

[1] XU Caixia, LU Ping. Research on the Construction Path of Double Qualified Teachers Team based on the Cultivation of Applied Talents in Transitional Colleges and Universities[J].Hebei Vocational Education,2016,(6).

[2] WANG Guihong. Thinking on the Construction of Double Qualified Teachers team in Applied Universities[J].Journal of Quanzhou Normal University,2017,(4).

[3] LI He. Research on the Cultivation Strategy of Double Qualified Teachers's Practical Ability under the Background of Transformation[J].Ability and Wisdom,2017,(24).

[4] BAI Lijun, HAN Bing, MA Chunxu. The Construction of Double Qualified Teachers Team based on the Cultivation of Applied Talents in Private Colleges and Universities[J].Ability and Wisdom,2016,(36).

[5] TIAN Jiya, LI Xiaoguang, WANG Guixing. Research on the Countermeasures of Double Qualified Teachers Training in the Transition Period of Private Colleges and Universities[J].Talent Resource Development,2017,(2).

[6] GUO Qiang. A Probe into the Training Path of Double Qualified Teachers in the University of Finance and Economics[J].Course Education Research,2016,(21).

[7] TIAN Xiaoqing. An Analysis of the connotation of Double Qualified Teacher team in Applied undergraduate Colleges and Universities[J].Time Education,2016,(17). 